\title{
MURRA AT MIT
}

\author{
Heather Lechtman ${ }^{1}$
}

Of all Murra's publications, there are two articles that I have always loved the best: Las etnocategorías de un khipu estatal (1975) and Cloth and Its Functions in the Inka State (1962). I assign these articles as required reading to undergraduate students in two of the courses I teach at MIT: The Ancient Andean World, and Materials in Human Experience.

The students in my classes are primarily engineers; others study physics or biology, architecture or economics. Some are from Mexico, and occasionally there are a few from the Andes. For the most part, they do not read Spanish.

Many years ago I asked Murra if he would translate the Etnocategorías article into English so that I could give it to my students to read. He made the translation but did not publish it. It is the only translation of Etnocategorías into English I know of.

I love this article of Murra because, after all, how is one to teach a group of engineering students about the meaning of ethnocategories when they have never attended a class in cultural anthropology? In The Ancient Andean World, the students read Ethnocategories after we have spent weeks discussing Andean microenvironments, vertical complementarity, and Murra's model of the vertical archipelago; the boundless varieties of maize and Andean potatoes, and the property of phenotypic plasticity that governs the flexibility of indigenous Andean biota; agriculture and cloth as dual forms of wealth in the Inka state; fibers as the materials through which major engineering achievements were carried out in the Andes.

The students then read Ethnocategories, and suddenly all the parts assemble into a structure that makes sense, a hierarchical set of cultural categories that integrate biological, economic, and technological orders of experience and of social commitment. And that order is assembled, expressed, and curated on a khipu through the manipulation of its fibers.
Whereas the Ancient Andean World focuses on the Andes in prehistory, the class on Materials in Human Experience covers a much broader intellectual, geographic, and temporal landscape. The class is something of an anthropology of technology, in which the sphere of technologies it covers is restricted to the management and manipulation of natural materials and the processing of those materials to transform them into items of culture.

The special attention of the class to the exploitation, processing, and design of materials results from the fact that the class is offered by MIT's Department of Materials Science and Engineering (DMSE). The fundamental anthropological structure of the subject matter, provided by the DMSE faculty members who teach it -Dorothy Hosler, a Mesoamericanist and Heather Lechtman, an Andeanist- is communicated through a series of case studies. Each case study explores the utilization of a specific type of engineering material by a specific society known to us primarily through archaeological research.

Like many engineering classes at MIT, Materials in Human Experience includes weekly laboratory (practicum) sessions during which students examine the properties of the material that the case study presents and discover how those properties were managed by the society in question.

In the spring of 2006, one of the engineering materials the class examined was fibers. The use of fiber technologies by the Inka state provided the case study context for our dual engineeringanthropological approach.

The students chose to construct a "giant" khipu as the laboratory component of their case ${ }^{1}$ study. They used as their model the information on the chart (Cuadro IV) Murra published in Etnocategorías which tabulates the items read into a court record in 1561 by a khipukamayoc from Hatun Xauxa. The Xauxa khipu recorded both the items that the community of Hatun Xauxa provided to the invading

1 Massachusetts Institute of Technology, Cambridge MA 02139, USA. lechtman@mit.edu 
Spaniards over a period of 15 years as well as the items that the Spaniards looted from the Xauxa imperial warehouses during that same period.

The students built their khipu to record the information that documents the first historical encounter

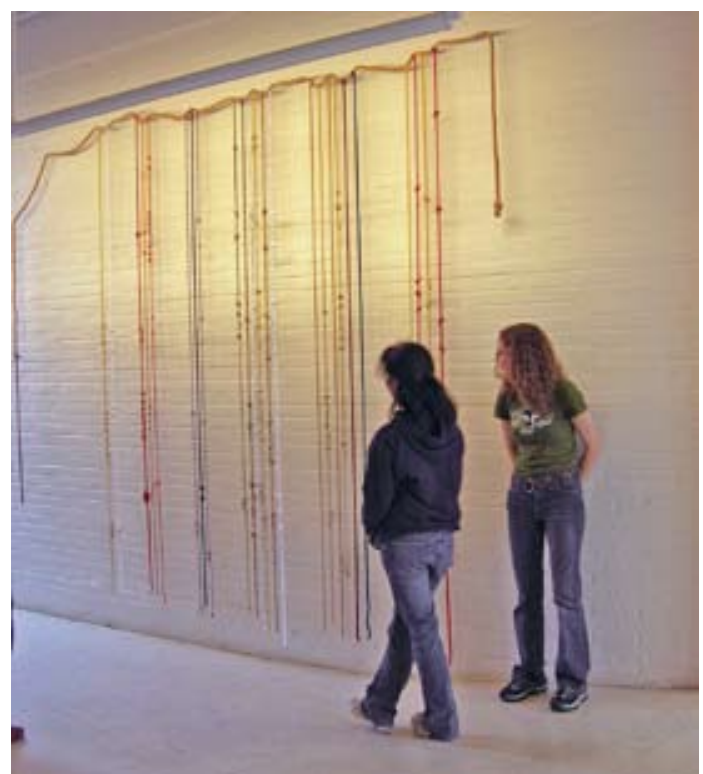

Figure 1. Students with their khipu.

Los estudiantes con su khipu. between Xauxa and the Spaniards: the entry of Francisco Pizarro and his army into Xauxa in 1533. They designed the khipu to hang, on exhibit, on a sun-bathed wall in the MIT building that houses the Department of Materials Science and Engineering. The width of the wall allowed them to reconstruct only the first six categories of pendant cords on the original Xauxa khipu -a total of 24 cords- read into the court record by the Xauxa khipukamayoc in 1561: I (men and women); II (camelids); III (cloth); IV (maize, quinua, potatoes); V (sandals, cargo straps, horse harnesses); VI (ceramic vessels).

The main cord of the students' khipu measures about 24 feet $(7.3 \mathrm{~m})$ in length; the pendant cords hang from a height of about 15 feet $(4.6 \mathrm{~m})$ (Figures 1,2). We purchased cotton knitting yarn of colors often used in Inka khipus and plied the yarns to make the cords: 2-ply for the pendants and 3-ply for the primary cord. Sometimes the students plied a pendant cord from yarns of two different colors.

The entire khipu was made by hand. Pendant cords representing goods provided to the Spaniards by the community at Xauxa were plied Z; goods looted by the Spaniards were plied S. Pendant cords representing goods provided were attached to the

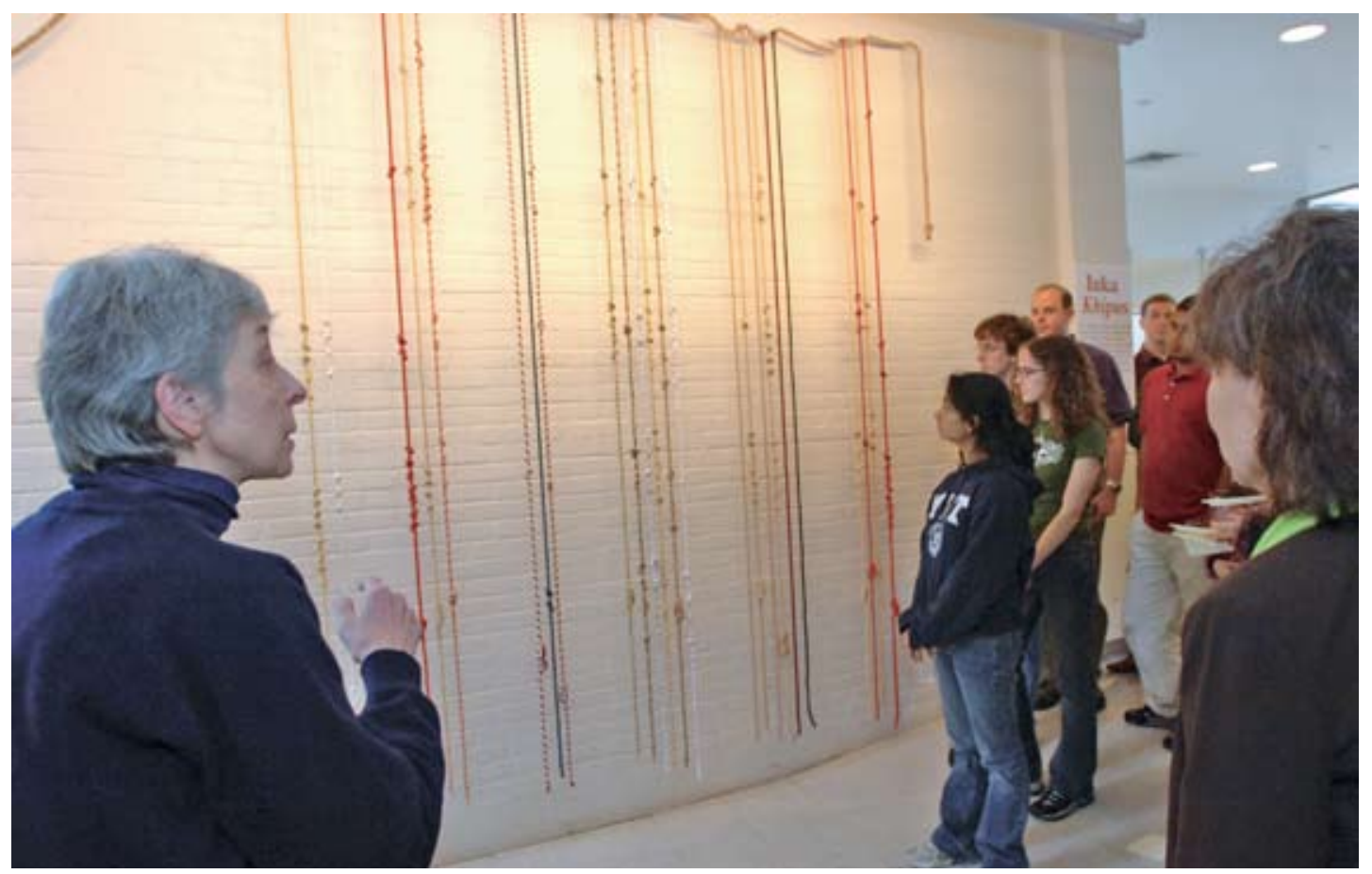

Figure 2. Heather Lechtman at the inauguration of the khipu. Heather Lechtman en la inauguración del khipu. 
primary cord by a 'half hitch recto' knot; goods looted were attached in the opposite direction, by a 'half hitch verso' knot. The students recorded the numbers on each pendant cord using only the variety of knots found on Inka khipus.

At the end of the semester, the students hung their khipu with great pride. At the inauguration of the exhibit they and I discussed with our audience Murra's Etnocategorías article, how he had interpreted and structured the Xauxa khipu from the court document, and the bases on which the students had made decisions about the construction of their khipu in order to communicate the information given in evidence by the khipukamayoc from Xauxa.

In the fall semester of each academic year MIT celebrates Parents Day, when the parents of the undergraduate students arrive to spend a weekend at the Institute. Every year the students who were enrolled in Materials in Human Experience 2006 bring their parents to see their khipu which still hangs on its sun-bathed wall. They show off their khipu with the same sense of pride with which they made it.

In my opinion, Coth and Its Functions in the Inka State is the best article Murra wrote-his tightest argument, the most compelling, the most powerful. It is a classic in the anthropological literature of the Andes.

In Materials in Human Experience we discuss Andean cloth and cloth production as only one manifestation of the Andean commitment to fibers as the quintessential material for use in solving fundamental engineering problems. Fibers for battle -slings as aggressive weapons and padded garments as defensive armor; fibers for the transport of goods- carrying cloths and costales; fibers for rope; fibers for reed boats; fibers for roofing thatch; fibers for khipus; fibers for long span suspension bridges; fibers for clothing. The Inka state inherited over 4,000 years of expertise in the manipulation of fibers and in the development of sophisticated fiber technologies by peoples throughout the Andes. It was obvious that the State's census-taking tool would be an implement of fibers, just as it was evident that only a flexible fiber caternary could span the deep ravines of the Khapaq Nan.

One morning in the early spring of 2007 , the faculty scheduled to teach Materials in Human Experience met, over coffee, to decide upon the case studies and laboratory projects for the class. Once again we selected fibers as an engineering material

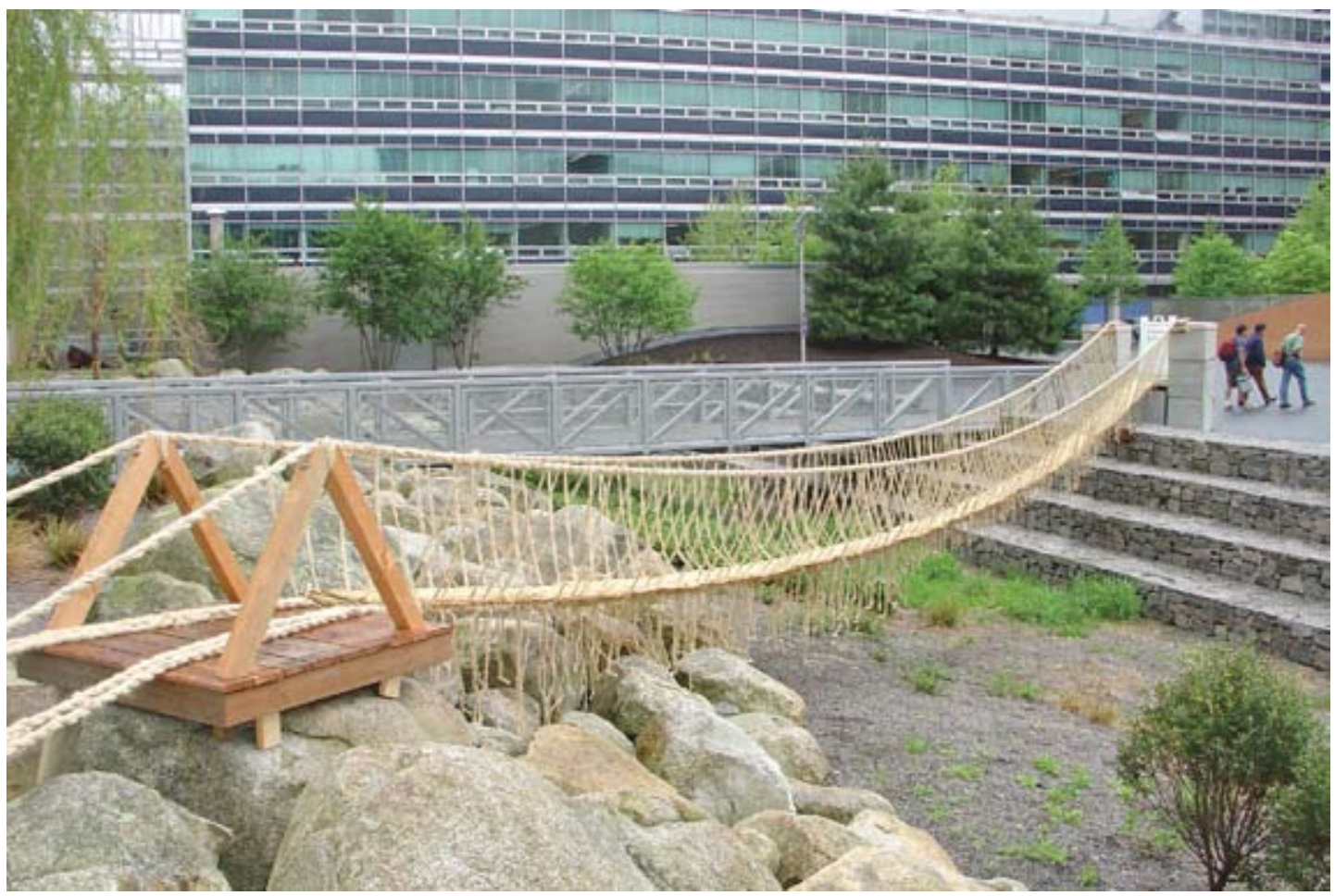

Figure 3. Chaka Stata. 


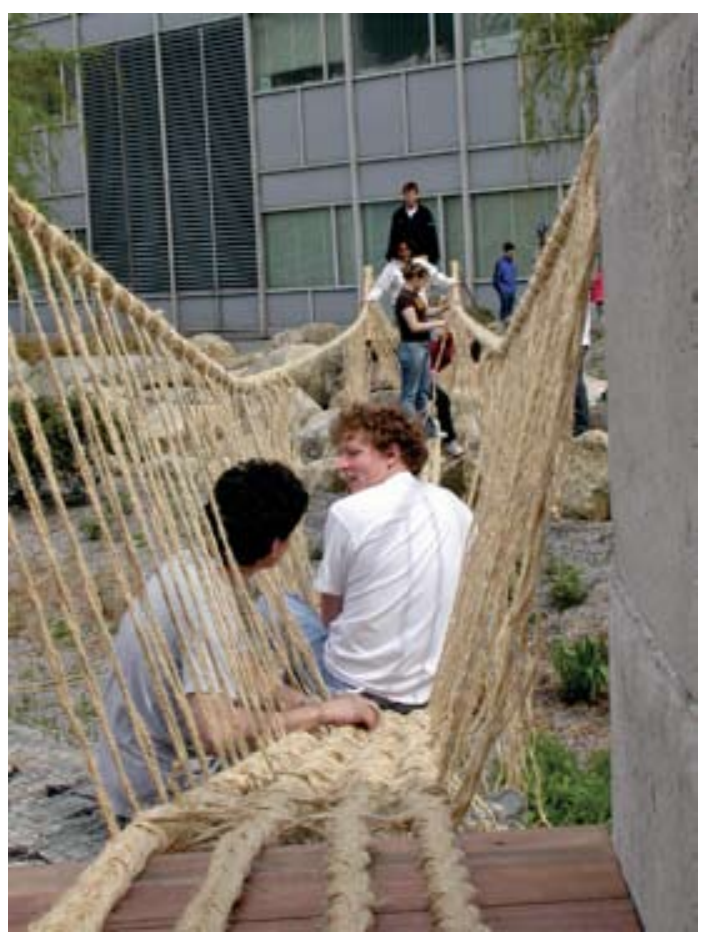

Figure 4. Students installing the Chaka Stata.

Estudiantes instalando el Chaka Stata.

to be explored and Twantinsuyu as the cultural and political entity within which that exploration would be developed. We were at a loss, though, to define an appropriate student laboratory project, especially in light of the great success that continued to surround the giant khipu of 2006.

Professor Hosler came up with the solution. Why not an Inka-style fiber suspension bridge that the students would build and install on the MIT campus, she suggested! We all agreed with enthusiasm to this ambitious but, we thought, manageable project. In the end, it was ambitious, designed and executed entirely by 14 students in the class. For the four-week period that it hung and swayed gently across a dry moat on campus, the Chaka Stata ${ }^{2}$ was the most beautiful and unexpected construction to grace the world's premier educational institution of engineering and science (Figures 3, 4).

Like the giant khipu, the students constructed the Chaka Stata by hand. As their model they used the suspension bridge renewed annually by the communities near Huinchiri, in highland Peru. In 1997 a crew from the PBS television program NOVA $^{3}$ filmed the three-day sequence of operations involved in gathering local grasses, spinning and plying grasses into rope, twisting ropes into primary cables, braiding primary cables into final cables, and installing the bridge over the Apurimac gorge at Huinchiri.

As a substitute for grasses, the students used twine made from sisal (agave/cabuya) fiber. We purchased 50 miles $(80.5 \mathrm{~km})$ of twine that they plied, twisted, and braided into four cables for the footpath and two cables for the handrails. Each final cable measured 175 feet $(53.4 \mathrm{~m})$ in length, long enough to cross the 70 foot $(21.4 \mathrm{~m})$ span of the dry moat with sufficient excess cable to secure the ends to the two stone or concrete ramparts that they had built.

For four weeks anyone walking across the MIT campus stopped at the chaka. No one passed it by. Everyone smiled. It was beautiful: perfectly designed, perfectly engineered, perfectly executed. The students formed teams; each week one team was responsible for tightening the footpath cables to maintain the appropriate degree of sag. Many people walked across the chaka. Most just stopped and gazed.

In 2006 during a visit to John Murra in Ithaca, I told him about the giant MIT khipu constructed on the basis of his Etnocategorías article and that we planned a public inauguration of the exhibit. He responded: Shouldn't I be there? By then he was confined to bed.

Murra never saw photos of the Chaka Stata. He would have been delighted by the international coverage of the students' Andean bridge, which appeared on the front page of The New York Times, Science Times (8 May 2007) and in El Comercio, Lima (22 May 2007). And we both would have smiled, contemplating the sixteen year old Vassar College physics student whom he taught in 1952, guiding young MIT engineers in the communal construction of an Inka chaka.

July 31, 2007 


\section{References Cited}

Murra, J.V.

1962 Cloth and its functions in the Inka State. American Anthropologist 64:710-728.

\section{Notes}

1 In 2003, the Museo Chileno de Arte Precolombino constructed a truly "giant" khipu for the exhibit of Andean prehistoric khipus that the museum mounted to coincide with the Congreso Internacional de Americanistas that took place in Santiago de Chile in July of that year.

2 The students installed their chaka across a dry moat on the MIT campus that is located in the plaza adjoining a building
1975 Las etnocategorías de un khipu estatal. In Formaciones Económicas y Políticas del Mundo Andino. Instituto de Estudios Peruanos, p. 243-254, Lima.

known as the Stata Center. The suspension bridge bears the name of that building and plaza.

3 NOVA is a television program devoted to science. It is sponsored by WGBH, a TV station in the United States that is part of the Public Broadcasting System. 
